\title{
Chemical characteristic, lactic acid bacteria population, and angiotensin converting enzyme inhibitory activity of traditional fermented beef "cangkuk" by spontaneous fermentation with the addition of bamboo shoot
}

\author{
I. Mirdhayati* and W. N. H. Zain \\ Faculty of Agriculture and Animal Science, State Islamic University Sultan Syarif Kasim Riau, \\ Jl.H.R. Soebrantas km15,5 Pekanbaru 28293 - Indonesia \\ *Corresponding E-mail :mirdhayati@gmail.com \\ Received February 07, 2020; Accepted June 24, 2020
}

\begin{abstract}
ABSTRAK
Penelitian ini bertujuan untuk menguji sifat kimia, populasi bakteri asam laktat (BAL) dan aktivitas inhibitor angiotensin converting enzyme (ACE) daging sapi yang difermentasi dengan penambahan rebung bambu. Penelitian menggunakan Rancangan Acak Lengkap Faktorial dua faktor. Faktor A yakni metode preparasi rebung : dicacah, digiling, dan diekstrak. Faktor B adalah rasio daging dan rebung (B) yakni $1 ; 0,75 ; 1: 1,1: 1,25$. Parameter kimia yang diamati adalah protein total, protein terlarut, derajat hidrolisis, $\mathrm{pH}$, total asam tertitrasi. Data kimia dan jumlah BAL dianalisis dengan sidik ragam, sedangkan aktivitas inhibitor ACE dianalisis deskriptif. Hasil penelitian menunjukkan bahwa metode preparasi rebung dengan cara digiling dan diekstrak mampu menurunkan total protein dan nilai $\mathrm{pH}$. Rasio daging sapi dan rebung 1:0,75 dan 1:1 mampu menurunkan protein total dan meningkatkan total asam tertitrasi. Interaksi faktor A dan faktor B hanya terjadi pada peningkatan derajat hidrolisis. Faktor A dan B tidak nyata terhadap jumlah bakteri asam laktat. Aktivitas inhibitor ACE yang dihasilkan berkisar 36,5-79,6\%. Dapat disimpulkan bahwa metode preparasi rebung bambu dengan cara digiling dan rasio daging : rebung 1:0,75 dan 1:1 dapat meningkatkan derajat hidrolisis dan memiliki aktivitas inhibitor ACE yang tinggi.
\end{abstract}

Kata kunci : cangkuk, daging fermentasi, rebung, sifat kimia, inhibitor ACE

\begin{abstract}
This research was conducted to examine the chemical properties, lactic acid bacteria (LAB) population and angiotensin converting enzyme (ACE) inhibitory activity of fermented beef meat with the addition of bamboo shoots. This research used factorial completely randomized design. Factor A was the preparation method of bamboo shoots: chopped, ground, and extracted. Factor B was the ratio of meat and bamboo shoots (B) which was 1:0.75, 1:1, 1:1,25 ratios. The chemical properties observed were total protein, soluble protein, hydrolysis degree, $\mathrm{pH}$ and titratable acidity value. The results showed that bamboo shoot preparation methods by ground and extracted were able to reduce total protein, and $\mathrm{pH}$ value. The ratio of meat and bamboo shoot (1:0.75 and 1:1) were able to decreased total protein but increased total titratable acidity. The interaction of the factors $\mathrm{A}$ and factor $\mathrm{B}$ only occurred in increasing hydrolysis degree. Both of two factors (A and B) could not significantly effect to the number of LAB. The ACE inhibitory activity ranged from 36.5 to $79.6 \%$. It can be concluded that the preparation methods of bamboo shoots by ground and 1: 0.75 and 1: 1 of beef : bamboo shoot ratio could increase
\end{abstract}


hydrolysis degree and had highest ACE inhibitory activity.

Keywords: cangkuk, fermented meat, bamboo shoot,chemical properties, ACE inhibitory activity

\section{INTRODUCTION}

Fermented food products have long been known to the Indonesian people. These foods made from various sources such as vegetable, grain, milk and meat. The traditional types of fermented products from buffalo milk known as "dadih" originally from West Sumatra and danke from South Sulawesi (Soenarno et al., 2013). Indonesian local fermented products derived from meat are not widely known. One of the traditional fermented meat products is "cangkuk".

According to Salahuddin (2004), "cangkuk" is a traditional fermented product derived from buffalo meat added with betung bamboo shoot (Dendrocalamus asper) and salt, originally from Sorolangun District, Jambi Province. "Cangkuk" was made for special events such as in the holy month of Ramadan, a family celebration and feast days. Cangkuk is also known by the people in Kuantan Singingi District, Riau Province. With the same designation, cangkuk was processed using meat, particularly beef meat. The processing and additive materials used are also similar to those in Sorolangun District, Jambi. The additive materials used were salt, rice, water and bamboo shoot.

Bamboo shoot was prepared by people in Riau Province before consumed in two types of processing methods, namely boiling and fermentation. Bamboo shoot was fermented by using indigenous microbes of its self and added salt at 1-5\% w/w. In "cangkuk" processing, both of bamboo shoot and beef meat were fermented together with the addition of rice and salt in certain concentrations. Bamboo shoot and rice contribute in nutrient supply for indigenous microbes during fermentation hence they had high carbohydrate. Salt in lower concentration contributes in mineral supply. Choudhury et al. (2012), said that bamboo shoot had high moisture and carbohydrate content, protein and mineral. Bamboo shoot had an active material such as vitamin, amino acids, antioxidant and steroids.

Recent research on fermented meat products has been widely reported. Dry-cured ham is a type of fermented pork, seasoned and followed by spontaneous fermentation for 10-11 months. Fermented meat products named according to the country or place of origin, such as Spanish dry- cured ham originating from Spain (Escudero et al., 2012), Xuanwei Ham (Li et al., 2003) and Jinhua Ham from China (Zhou and Zhao, 2007). Fermented sausage known as salami, such as salami Milano from Italy (Ruiz et al., 2014), Chorizo (Broncano et al., 2012) and Sremska sausage from Serbia (Zivkovic et al., 2012).

Based on these studies, it can be seen that fermented meat has the advantage as a source of bioactive peptides, free amino acids with a unique flavor, do not contain pathogenic bacteria and better sensory properties. The two physiological functions shown are as antioxidants and antihypertensive (Escudero et al., 2012; Albenzio et al., 2017).

In Southeast Asia, fermented meat products are known as sour meat which is processed to increase consumers' needs in choosing the variety of foods they want. Meat products are inoculated with microbes at controlled time and processing conditions to produce the desired properties. Local producers generally use natural fermentation without inoculation or controlled conditions. The microorganisms found in products come from the meat itself or the environment (Singh et al., 2012). A number of active components physiologically including bioactive peptides have been found in traditional fermented food. Therefore, traditional fermented meat is an interesting target for a new functional meat product (Arihara, 2006).

The "cangkuk" remain produced and consumed by the community in certain age groups ( $>50$ years) in Riau Province. The presumption of the community that consuming "cangkuk" was in accordance with the tastes of the elderly, a tender texture, a specific aroma and taste was a little sour that was preferred. Yana et al. (2016) stated that the similar traditional food, fermented pork meat (tamba) from Dayak Bulusu north Kalimantan, had a specific flavor preferred. Meanwhile, there has been no scientific evidence reported and studied in bioactivity of traditional fermented meat, particularly "cangkuk". Furthermore, research on Indonesian traditional fermented meat products is very limited. "Cangkuk", that produced by spontaneous fermentation of beef meat with addition of bamboo shoot could, generated new source of the bioactive peptide.

The bioactive peptide from food remains 
interesting to study because they have beneficial effect to immunity, inflammation, infection, hypertension, hypercholesterolemia, diabetes, some cancer and neurological problems. Both of meat and meat product have been described as a very good source of angiotensin converting enzyme (ACE) inhibitory peptides. Several processing methods of meat, namely enzymatic hydrolysis by using commercial protease, fermentation, thermal processing have been reported that its product had potent angiotensin converting enzyme (ACE) inhibitory activities (Mora et al., 2018). The role of ACE inhibitory peptide is to maintain the balance between vasoconstrictive and salt-retentive effect of angiotensin II and vasodilator effect of bradykinin. Thus, inhibiting the formation of angiotensin II by ACE inhibitory peptide lead blood pressure lowering effect (Wu et al., 2017). In this research, fermented beef meat had been done by adding bamboo shoot, without using starter culture and were fermented in anaerobic condition during one week at room temperature. Fermentation process by using natural microbe within raw material known as spontaneous fermentation. In this research, measuring the ACE inhibitory activity was conducted to know the potency of traditional fermented beef meat as source of the bioactive peptide. Furthermore, measuring the total protein, the soluble protein content, degree of hydrolysis, $\mathrm{pH}$ value and total titratable acidity were conducted to describe the chemical characteristic and to know degree of hydrolysis by microbial enzyme after fermentation process. The total lactic acid bacteria was measured to know the product safety after fermentation process.

\section{MATERIALS AND METHODS}

The materials used in processing of beef meat fermented "cangkuk" were fresh beef meat (brisket) from male Bali cattle with 2.5-3 years old purchased from Animal Slaughtering House in Pekanbaru city. The green bamboo shoots were harvested from local farms in Kampar Regency. Additive ingredients were rice and salt and distilled water. Chemicals used in analysis of chemical characteristic were sulphuric acid, hydrogen chloride, sodium hydroxide, boric acid, catalyst selenium, trichloroacetic acid, Lowry reagent, Bovine Serum Albumin (BSA), Folinciocalteau and distilled water. The chemical used in ACE inhibitory activity analysis were angiotensin converting enzyme of rabbit lung (Sigma), hippuryl-hystidyl-leucyne substrate (Sigma), sodium chloride, sodium borate buffer pH 8.3 and ethyl acetate. Analysis of lactic acid bacteria used medium MRSA (de Man Rogosa Sharpe agar) (Merck). All of chemicals and reagent were analytical grade.

The equipment that used to prepare bamboo shoot were a knife, plastic ware, analytical balance measurement, blender, glassware, volumetric flask, tube centrifuge, and high speed centrifuge. The instrument that used for analysis of "cangkuk" were mortar, $\mathrm{pH}$ meter, Kjeltec set, burette flask, spectrophotometer UV-Vis, waterbath, magnetic stirrer, micropippet, oven, petri dish, autoclave and colony counter.

\section{Preparation of Bamboo Shoot}

Bamboo shoots were harvested from local farms in Kampar Regency and brought to the laboratory in order to remove their skin and smooth hair. Bamboo shoot washed and drained, followed by thinly sliced. There were three preparation methods of bamboo shoot (factor A) in this experiment, namely: chopped (A1), ground (A2) and extracted (A3). A1 was prepared with this following: bamboo shoots were chopped into small pieces by using a knife. A2 was prepared by mixing the bamboo shoot and distilled water in 1:1 ratio, homogenized within blender for 3 minutes. A3 was prepared by mixed bamboo shoot and distilled water with $1: 3$ ratio, homogenized within blender for 3 minutes. Then, water soluble extracts were obtained by centrifugation at a speed of $6,000 \mathrm{rpm}$ for 30 minutes. Supernatant was taken as a water soluble extract. Factor $\mathrm{B}$ was prepared by weighing bamboo shoot based on their ratio of meat weight, $1: 0.75 ; 1: 1$ and $1: 1.25$, respectively.

\section{Preparation of Beef Meat}

The fresh beef meat, part of the brisket, was purchased from Animal Slaughtering House in Pekanbaru city which was put in the ice box and brought to the laboratory in the cold condition. Further processing conducted by separating the fat and connective tissue of the meat and washed with distilled water and then drained at room temperature. The meat was cut into small pieces with size $5 \times 5 \times 2 \mathrm{~cm}^{3}$.

\section{Processing of the Cangkuk}

This stage was aimed to conduct fermentation of "cangkuk" according to the 
Salahuddin (2004) and general method in Riau Society. Fermented beef meat "cangkuk" was initially prepared $300 \mathrm{~g}$ of small cuts of beef meat for each experimental unit. Then, bamboo shoots were placed based on their preparation methods (chopped, ground, a water soluble extract) and ratios to meat weight, i.e: $1: 0.75 ; 1: 1$ and $1: 1.25$ $(225 \mathrm{~g}, 300 \mathrm{~g}$ and $375 \mathrm{~g})$. Both of meat and prepared bamboo shoot were put into each of polypropylene plastic boxes based on their treatments. Bamboo shoot based on their treatments was mixed with beef meat, salt and rice. Salt and rice were added at $1 \%$ from total weight beef meat and bamboo shoot. All of the ingredient was mixed homogeneously and then covered tightly. Fermentation process was in anaerobic condition during seven (7) days at room temperature $\left(27-28^{\circ} \mathrm{C}\right)$. Yana et al. (2016), stated that fermentation process occurred naturally by using indigenous microbe within raw material (without adding culture starter), known as spontaneous fermentation. After the fermentation process, fermented beef meat ("cangkuk") was separated from another ingredient and was packed in laminated aluminium-plastic, then kept in freezer at $-20^{\circ} \mathrm{C}$ for further analysis. The analyzed variable of "cangkuk" were total protein, soluble nitrogen (protein) content, degree of hydrolysis, $\mathrm{pH}$ value, titrable acidity, number of lactic acid bacteria and ACE inhibitory activity.

\section{Analysis of Total Protein by Micro Kjeldahl Method}

Analysis total protein of the sample was conducted by micro-Kjeldahl method (AOAC 960.52). The samples analyzed consisted of fresh beef before fermentation and the fermented beef meat ("cangkuk") from each treatment.

\section{Analysis of Soluble Nitrogen (Protein) in Trichloroacetic Acid (SN-TCA)}

An amount of $20 \mathrm{~mL}$ of fermented beef meat was added with $20 \%$ TCA (w/v) of $20 \mathrm{~mL}$. The mixture is then allowed to stand for 30 minutes for sedimentation and then centrifuged (speed of $7,800 \mathrm{x} \mathrm{g}$, for 15 minutes). The supernatant was then analyzed for nitrogen content using the Lowry method (Waterborg, 2002). An aliquot of $0.5 \mathrm{~mL}$ of the sample was mixed with $5.5 \mathrm{~mL}$ of an alkaline-copper reagent and incubated for 20 min at room temperature. The mixture was added to $0.5 \mathrm{~mL}$ Folin-Ciocalcetau's phenol reagent at 8fold dilution with distilled water and allowed to stand for $30 \mathrm{~min}$. Absorbance was measured at $750 \mathrm{~nm}$ using spectrophotometer. Bovine serum albumin (BSA) was used as standard.

\section{Degree of Hydrolysis}

The degree of hydrolysis measured according to procedures of Hasnaliza et al., (2010), which is calculated based on the percentage ratio of soluble protein in trichloroacetic acid (TCA) to total protein content of the fermented beef meat. The degree of hydrolysis can be calculated by the following formula:

$\%$ Degree of Hydrolysis $=[$ Soluble Nitrogen in TCA 20\% (w/v)] / Total protein x $100 \%$

\section{pH analysis}

An amount of five grams of finely ground samples of fresh beef meat before fermentation and fermented beef meat "cangkuk" from each treatment were prepared. Then, add the distilled water $10 \mathrm{ml}$ and stir until evenly distributed. The $\mathrm{pH}$ value is measured using a $\mathrm{pH}$ meter that has been calibrated with a buffer of $\mathrm{pH} 4.0$ and $\mathrm{pH}$ 7.0 .

\section{Total Titratable Acidity}

Total titratable acidity was measured using the principle of lactic acid base. Amount of ten mg sample was put into the Erlenmeyer flask, then added 2-3 drops of $1 \%$ phenolphthalein indicator. Samples were titrated with $0.1 \mathrm{~N} \mathrm{NaOH}$ solution until they formed a pink color and did not disappear within 30 seconds (Rahman et al., 1992). The total titratable acidity calculated by the formula:

Total titratable acidity $(\%)=[\mathrm{V} \mathrm{NaOH} \times \mathrm{N}$ $\mathrm{NaOH} \times(90 / 1,000)] /($ sample volume $)\} \times 100 \%$

\section{Number of Lactic Acid Bacteria}

The number of lactic acid bacteria colonies was determined by pour plate method and analyze using the Standard Plate Count (SPC). The deMan Rogosa Sharpe Agar (MRSA) used as the propagation medium of lactic acid bacteria. A sample of $1 \mathrm{mg}$ of inoculant pipetted into a sterile Petri dish and then the MRSA medium which has cooled (temperature about $37^{\circ} \mathrm{C}$ ) is poured into sterile Petri dish as much as $12-15 \mathrm{~mL}$. The mixture is homogeneous by moving the Petri dish. Petri dishes were incubated upside down after hardening, at $37^{\circ} \mathrm{C}$ for $24-48$ hours. All analyses were done in duplo. The number of colonies per 
gram (as $\log _{10}$ of CFU/g for each sample) is calculated using the formula:

Number of colonies $/ g=$ Number of colonies per petri dish $\times(1 /$ dilution factor $)$

\section{Measurement of ACE inhibitory activity}

The ACE inhibitory activity was measured according to the method of Chusman and Cheung (1971) with modification by Arihara et al. (2001). This assay based on the liberation of hippuric acid from Hip-His-Leu catalyzed by ACE. Amount of $20 \mathrm{~g}$ "cangkuk" was ground and added $20 \mathrm{~mL}$ distilled water, mixed homogenously and filtered by filter paper to prepare sample solution. A sample solution $(15 \mu \mathrm{L})$ was mixed with $125 \mu \mathrm{L}$ of $100 \mathrm{mM}$ sodium borate buffer $(\mathrm{pH} 8.3)$ containing $7.6 \mathrm{mM}$ Hyp-Hys-Leu and $608 \mathrm{mM}$ $\mathrm{NaCl}$ and then pre incubated for $5 \mathrm{~min}$ at $37^{\circ} \mathrm{C}$. The reaction was initiated by the addition of 50 $\mu \mathrm{L}$ of ACE dissolved in distilled water, and the mixture was incubated for $30 \mathrm{~min}$ at $37^{\circ} \mathrm{C}$. For the blank, distilled water was used about $50 \mu \mathrm{L}$. The reaction was stopped by adding $125 \mu \mathrm{L}$ of $1 \mathrm{~N}$ $\mathrm{HCl}$. The hippuric acid liberated by ACE was extracted by adding $750 \mu \mathrm{L}$ ethyl acetate to the mixture with vigorous shaking. After centrifugation at $12,000 \mathrm{rpm}$ for $10 \mathrm{~min}, 500 \mu \mathrm{L}$ of the upper layer was collected and then dried at $90^{\circ} \mathrm{C}$ for $60 \mathrm{~min}$. Hippuric acid was dissolved with $1 \mathrm{~mL}$ distilled water and photometrically was determined at $228 \mathrm{~nm}$. ACE inhibitory activity was calculated using the equation:

Inhibitory activity $(\%)=[(\mathrm{C}-\mathrm{A}) /(\mathrm{C}-\mathrm{B})] \times 100$ where A: absorbance of sample reaction, $\mathrm{B}$ : absorbance of the blank, $\mathrm{C}$ : absorbance of control (distilled water for the sample).

\section{Data Analysis}

Analysis of total protein, soluble protein, degree of hydrolysis, $\mathrm{pH}$ value, total titratable acidity, and the number of lactic acid bacteria were statistically analyzed by analysis of variance with a completely randomized factorial with three replications. Factor A is the preparation method of bamboo shoots: chopped, ground, and extracted. Factor B is the ratio of meat and bamboo shoots (B) which is $1,0.75 ; 1: 1,1: 1.25$ ratios. Post hoc analysis was carried out by the Duncan Multiple Range Test (DMRT) to see the difference between treatments (Steel and Torrie, 1980). Bioactivity data of ACE inhibitory activity were analyzed by calculating the mean and standard deviation.

\section{RESULTS AND DISCUSSIONS}

\section{Chemical Characteristics}

Total protein of "cangkuk" were presented in Table 1. Total protein of raw beef meat before fermentation process was $18.95 \pm 0.30(\mathrm{~g} / 100 \mathrm{~g})$. This research showed that preparation methods of bamboo shoot (factor A) by ground and extracted could decrease the total protein of "cangkuk" greater than by chopped during spontaneous fermentation for one week $(\mathrm{P}<0.01)$. In term of the ratio of meat and bamboo shoot (factor $\mathrm{B}$ ), 1:0.75 and 1:1 ratios could decrease the total protein greater than $1: 1$ and $1: 1.25$ ratios $(\mathrm{P}<0.01)$. There were no interactions between factor A and factor B to decrease the total protein. This research showed that addition of bamboo shoot with different preparation method on fermentation process without adding culture starter of beef meat contributes in change total protein value after fermentation. This phenomenon similar with Zhou et al. (2017), studied on fermentation of solid beef inoculated with two starter cultures (Lactobacillus curvatus and Pediococcus pentosaceus) in different inoculums concentration, fermentation time and fermentation temperature. An increase of inoculums concentration, fermentation times and fermentation temperatures could decrease protein composition in term water-soluble protein and salt soluble protein after fermentation, while insoluble protein increased.

Bamboo shoot became nutrient source for indigenous microbe during spontaneous fermentation in this research due to had high content of moisture, carbohydrate, protein and mineral. Bamboo shoot had an active material such as vitamin, amino acids, and steroids (Choudhury et al., 2012). It can be seen in Table 1 , both of the preparation method of bamboo shoot and bamboo shoot ratios could decrease the total protein in the different way. It is shown that the preparation method by using ground and extracted could decrease total protein greater than by chopped. The size reduction of bamboo shoot using blender facilitated fermentation progress more compared to the chopped method. Furthermore, meat and bamboo shoot ratios showed that decreased the total protein was greater at 1:0.75 and $1: 1$ than $1: 1$ and 1:1.25. This finding showed that the bamboo shoot ratio must be lower and similar with than beef meat, at the high ratio 1.25 the total protein decreased more smaller due to fermentation progress was lower. 
Table 1. Preparation Method, Meat and Bamboo Shoot Ratios and Their Interactions on Total Protein, Soluble Protein, Degree of Hydrolysis, $\mathrm{pH}$ Value, Titratable Acidity and Lactic Acid Bacteria of Fermented Beef Meat "cangkuk"

\begin{tabular}{|c|c|c|c|c|c|c|c|c|c|}
\hline \multirow[t]{2}{*}{ Parameters } & \multicolumn{3}{|c|}{$\begin{array}{l}\text { Preparation Method } \\
\text { (Factor A) }\end{array}$} & \multicolumn{3}{|c|}{$\begin{array}{c}\text { Meat : Bamboo Ratios } \\
\text { (Factor B) }\end{array}$} & \multicolumn{3}{|c|}{ Significance } \\
\hline & $\mathrm{C}$ & $\mathrm{G}$ & WSE & $1: 0.75$ & $1: 1$ & $1: 1.25$ & PM & MBR & INT \\
\hline \multicolumn{10}{|l|}{ Chemical charactheristics } \\
\hline Total Protein $(\mathrm{g} / 100 \mathrm{~g})$ & 16.62 & 15.02 & 15.25 & 14.85 & 15.61 & 16.43 & $* *$ & $* *$ & ns \\
\hline Soluble Protein $(\mathrm{g} / 100 \mathrm{~g})$ & 0.46 & 0.44 & 0.32 & 0.39 & 0.40 & 0.44 & $* *$ & ns & ns \\
\hline Degree of Hydrolysis (\%) & 2.83 & 2.97 & 2.13 & 2.66 & 2.61 & 2.66 & $*$ & ns & $*$ \\
\hline pH Value & 4.67 & 4.57 & 4.40 & 4.58 & 4.45 & 4.59 & $*$ & ns & ns \\
\hline Titratable Acidity (\%) & 0.79 & 0.84 & 0.94 & 1.03 & 0.84 & 0.70 & Ns & $* *$ & ns \\
\hline \multicolumn{10}{|l|}{ Total bacteria } \\
\hline $\begin{array}{l}\text { Lactic Acid Bacteria } \\
\left(\log _{10} \mathrm{CFU} / \mathrm{g}\right)\end{array}$ & 7.11 & 7.11 & 7.05 & 7.17 & 7.07 & 7.03 & Ns & ns & ns \\
\hline
\end{tabular}

Data were presented by average value from three replications. Factor A was preparation method of bamboo shoot, consist of $\mathrm{C}=$ Chopped, $\mathrm{G}=$ Ground, WSE = Water Soluble Extract. Factor B was meat and bamboo shoot ratios : $1: 0.75 ; 1: 1 ; 1: 1.25$. PM = Preparation Method, MBR = Meat and Bamboo Shoot Ratios, INT $=$ Interaction between Preparation Method and Meat and Bamboo Shoot Ratio, **= highly significant $(\mathrm{P}<0.01) ; *=$ significant $(\mathrm{P}<0.05) ; \mathrm{ns}=$ not significant $(\mathrm{P}>0.05)$

The main component of meat is a protein (range from 15-22 g/100 g) which consists of high essential amino acid percentage. Beef protein composition of red meat with adipose tissues is about $18 \%$. During "cangkuk" processing, the fermentation occurs spontaneously with the help of mix salt and rice as additional ingredients on anaerobic condition. Fermented meat according to Hui (2006) is a fermentation process which consists in the growth and development of the microbial flora. This process naturally present in the meat during spontaneous fermentation or by the addition of starter culture. During the fermentation process, protein of beef meat was hydrolyzed by indigenous proteolytic enzymes from spontaneous microbes within the meat and bamboo shoot generated low molecular weight of protein (i.e: water-soluble protein), bioactive peptides and free amino acid (Steinkraus, 2002; Ockerman and Basu, 2017).

The preparation method of bamboo shoot by ground indicated that decreased in total protein during fermentation in line with increasing the soluble protein and percentage of hydrolysis degree. The phenomenon decreased of protein total during fermentation in line with increasing the soluble protein in this research was similar with traditional fermented fish of "Wadi betok" (Khairina et al., 1999), which reported the total protein of Anabas testudineus fresh fish higher than fermented fish. Decreasing total protein due to proteolytic activity by microbial enzyme break down the protein into small peptides and amino acid, thus the soluble protein content became increase. The treatment was adding $10 \% \mathrm{w} / \mathrm{w}$ salt to the weight of the fish and fermented for 12 weeks showed the increasing of soluble protein occurred at fourth day of fermentation process and continued until the 15 th days. Since a peptide is a lower molecular weight protein, it could be the one of the components of soluble protein which was measured by SN-TCA methods. The soluble protein of fermented beef "cangkuk" with different preparation methods and a ratio between meat and bamboo shoot was shown in Table 1 .

Based on the analysis of variance, the differences of preparation method of fermented beef "cangkuk" has a very significant effect to increase the soluble protein value $(\mathrm{P}<0.01)$, while the ratio of meat and bamboo shoot has not significantly 
effect on the value of soluble protein $(\mathrm{P}>0.05)$ of fermented beef "cangkuk". And also, there were no interactions between preparation methods and ratio of meat and bamboo shoot to soluble protein value. The increasing of soluble protein in this research was similar with Radiati et al. (2020), the addition of culture starter Lactobacillus plantarum with concentration $0-30 \mathrm{~mL}$ could increase soluble protein content of fermented goat meat "dendeng". Increasing soluble protein content due to proteolytic activity of bacterial enzymes to break down protein into peptides and hydrolyzed peptides into smaller ones and free amino acids.

The preparation methods of bamboo shoot by using chopped and blended produced the soluble protein content higher than by using extraction methods. The lower soluble protein content in extraction method was caused by water soluble extracts had reduction in the nutritional components of bamboo shoots due to some carbohydrate (starch, fiber) and water-insoluble compound (lipid) were wasted on the separation of water insoluble bamboo shoot components at centrifugation process. This directly caused the lower progress of fermentation as evidenced by the low level of hydrolysis degree, low content of soluble protein, but total protein still high. Starch, fiber and lipid were important nutrient for the microbe during fermentation (Kampen, 2014).

Degree of hydrolysis describes the percentage of peptide bond that cleaved during hydrolysis by the proteolytic enzyme of indigenous microbes on fermentation of beef meat. Degree of hydrolysis of fermented beef with different preparation method and ratio between meat and bamboo was shown in Table 1. Analysis of variance showed that the interaction of preparation method and ratio of meat and bamboo shoot had a significant effect to increase the degree of hydrolysis of fermented beef. The combination of treatment A2B2 (ground method and ratio meat : bamboo shoot 1:1) had the highest degree of hydrolysis. The increasing of hydrolysis degree in line with the decreasing of total protein and increasing the soluble protein. In this research, ground method of bamboo shoot and 1:1 ratio in "cangkuk" processing could decrease higher in total protein and increase soluble protein more greater, consequently the degree of hydrolysis became higher $(3.38 \%)$.

Degree of hydrolysis is a key parameter of hydrolysis reaction and used for monitoring progress of hydrolysis, describes the percentage of peptide bond that cleaved during hydrolysis, then generated smaller peptide with lower molecular weight (Nielsen et al., 2001). Soluble protein measured in this research based on soluble nitrogen compound that in trichloroacetic acid $20 \%$, they could be smaller peptides (Rutherfurd, 2010). During hydrolysis, a wide variety smaller peptide and free amino acid were generated, depending on enzyme specificity (Faithong et al., 2010).

Degree of hydrolysis from fermented beef meat in this research had lower $(2.0-3.3 \%)$ percentage than the degree of hydrolysis of fermented egg shell membrane by using lactic acid bacteria culture starter (25.1\%) (Jain and Anal, 2017). According to Faithong et al. (2010), degree of hydrolysis of Thailand traditional fermented shrimp and krill product, Jalo, Kongshom and Kapi were 25\%, 25-40\% and 20-22\%, respectively. The degree of hydrolysis of local fermented food was varied according to producers, raw material, additive ingredients, fermentation time and type of proteolytic microbial enzymes.

Variance analysis resulted that different preparation methods of bamboo shoot was significantly effect $(\mathrm{P}<0.05)$ to decrease the $\mathrm{pH}$ of fermented beef "cangkuk", meanwhile the different ratio of meat and bamboo shoot and interactions between the two factors showed a none significant effect $(\mathrm{P}>0.05)$ to $\mathrm{pH}$ value.

Fermented beef "cangkuk" prepared by addition of water soluble extract of bamboo shoot had lower $\mathrm{pH}$ value than the "cangkuk" that produced by addition of ground and chopped bamboo shoot, 4.40 contrasted with 4.57 and 4.67, respectively. The successive growth of microorganisms during meat fermentation was dominated by lactic acid bacteria which play an important role in the process. The lactic acid bacteria consume sugar primarily and carbohydrates and convert it into lactic acid, which lowers the $\mathrm{pH}$ (Ockerman and Basu, 2017). This psycho-chemical change called acidification, which has a preservative effect because its ability to inhibit spoilage and pathogenic microorganism (Bover-Cid et al. 2000).

Owens (2015) reported an indigenous fermented pork sausage from Thailand called Nham which fermented at room temperature for 3 - 4 days reached ultimate $\mathrm{pH}$ 4.6. In comparison to fermented meat cangkuk with different preparation methods of bamboo shoot, the $\mathrm{pH}$ value range from $4.40-4.67$. The same studies 
indicated that the primary microorganism during fermentation were associated to Lactobacilli and Pediococci. These certain lactobacilli identified as Lactobacillus plantarum, Lactobacillus pentosus and Lactobacillus sakei. While the pediococci observed as Pediococcus acidilactici and Pediococcus pentosaceus.

Another acidification process can be conducted by measuring the titratable acidity in fermented beef "cangkuk". The data in Table 1. showed that the titratable acidity calculated as a lactic acid percentage. Variance analysis resulted that different ratio of meat and bamboo shoot was very significantly effect $(\mathrm{P}<0.01)$ decreasing the titratable acidity of fermented beef "cangkuk", as different preparation methods and interactions between the two factors showed no significant effect $(\mathrm{P}>0.05)$.

The titratable acidity in this study was expressed as lactic acid because it is assumed that the bacteria were dominantly from lactic acid bacteria which perform the metabolic product of the carbohydrate breakdown into lactic acid. Source of carbohydrate during processing "cangkuk" derived from bamboo shoot and rice. The presence of lactic acid in the "'cangkuk" related to bamboo shoot and rice as raw material. As reported by Fuessl et al. (2012), the presence of lactic acid in fermented product because the carbohydrates within raw material were hydrolyzed into monosaccharides and then fermented under the absence oxygen by microorganisms into lactic acid. Related to $\mathrm{pH}$ of fermented beef "cangkuk" which indicated decrease value in line with the increasement of the titratable acidity.

Fermented beef "cangkuk" made with different ratios between meat and bamboo shoot was significantly decreased the titratable acidity percentage, which range from $1.03 \% ; 0.84 \%$ and $0.70 \%$, respectively. Fermented beef "cangkuk" having the 1.25 bamboo shoot ratio was significantly decreased compared to 0.75 ratio of bamboo shoot. This probably addressed by the presence of lactic acid.

Ockerman and Basu (2017) adduced the characteristics of different types of semi-dry fermented sausages has reduced $\mathrm{pH}$ to $4.7-5.3$ (lactic acid $0.5-1.3 \%$, total acidity $1 \%$ ), with a processing period of $1-4$ weeks. This finding has the same result with the titratable acidity of fermented beef "cangkuk" as shown in Table 1.

According to Umam et al. (2019), total titratable acidity of fermented goat meat "dendeng" with addition of culture starter Lactobacillus plantarum at concentration 0-30 mL could produce higher titratable acidity, ranging from $19-22 \%$. When compared with this research, the lower value of titratable acidity due to cangkuk processing was done with spontaneous fermentation without addition starter culture. This is emphasized that lactic acid production from spontaneous fermentation was lower than controlled fermentation by using culture starter.

\section{Number of Lactic Acid Bacteria}

Lactic acid bacteria play important role of lactic acid food fermentation, especially the lactic acid fermentation type of food. Variance analysis resulted that either the preparation method differences and different ratio of meat and bamboo shoot did not significantly affect $(\mathrm{P}>0.05)$ the lactic acid bacteria cell count.

The average cell count of lactic acid bacteria of fermented beef "cangkuk" in this research was $7 \log _{10} \mathrm{cfu} / \mathrm{g}$. It means that about 10 million of lactic acid bacteria were assumed to be present in the product. According to Kameník et al. (2013) the preliminary population of $6.5 \log _{10} \mathrm{cfu} / \mathrm{g}$ showed an increasement to $8.0-9.0 \log _{10} \mathrm{cfu} / \mathrm{g}$ of the lactic acid bacteria population until the peaking day of the 7 days of dry fermented sausage samples. Although the fermentation process of fermented beef "cangkuk" was conducted spontaneously, it reaches a high cell count of lactic acid bacteria.

The total of lactic acid bacteria in this research was higher than Umam et al. (2019) had been reported. Total of lactic acid bacteria of fermented goat meat "dendeng" with addition of culture starter Lactobacillus plantarum at concentration $0-30 \mathrm{~mL}$ ranging from 5.9 - 6.8 $\log _{10} \mathrm{cfu} / \mathrm{g}$. The higher of total lactic acid bacteria in "cangkuk" in line with increasing degree of hydrolysis and decrease total protein. Both of those action showed the enhanced proteolytic activity during fermentation which provides amino acid for the growth of lactic acid bacteria. There were several genera of lactic acid bacteria that generally found in fermented meat product, i.e. Lactobacillus, Pediococcus, Leuconostoc, Streptococcus and Enterococcus (Doyle et al., 2001).

Lindayani et al. (2018) reported that fermentation of yellow bamboo shoot could be source of lactic acid bacteria. Fermentation process occurred spontaneously (without addition culture starter) for one week with added brine 
solution at concentration $2.5 \%$ and $5 \% \mathrm{v} / \mathrm{W}$. According to Rahayu (2003), addition of brine solution during fermentation of vegetable could effect flavor formed by microorganism which occurred during fermentation.

\section{ACE Inhibitory Activity}

Angiotensin converting enzyme (ACE) inhibitory activity of fermented beef "cangkuk" from combination of preparation method and different ratio of bamboo shoot was seen in Figure 1. The combination of A2B1 had highest angiotensin converting enzyme activity (80\%). Similar result of ACE inhibitor activity also reported by Winarti et al. (2019), hydrolyzation of duck meat protein using Bacillus cereus TD5B protease, pepsin and trypsin showed that both Mojosari duck-meat and Magelang duck-meat had great ACE inhibitory activity and their activities were affected by type of used protease, ranging about $52 \%$ - 84\%. The best ACE inhibitor activity was showed by hydrolysate of Magelang duckmeat used trypsin.

According to Jamhari et al. (2013), meat of Bali cattle was hydrolyzed by using gastrointestinal protease (pepsin, trypsin and chymotrypsin) produced protein hydrolysate with ACE inhibitory activity $79 \%\left(\mathrm{IC}_{50}=341 \mu \mathrm{g} / \mathrm{mL}\right)$. When we compared with this research, traditional fermented Bali cattle "cangkuk" showed ACE inhibitory activity relative similar with hydrolysate of Bali cattle by using gastrointestinal protease. This is as evidence and emphasized that addition bamboo shoot as an ingredient additive, salt and rice in spontaneous fermentation of beef meat to produce "cangkuk" could produced fermented meat with potent ACE inhibitory activity. This indicated that local fermented product from Indonesia also had a functional effect as well as meat fermentation products typical of other countries.

Another local fermented product from Indonesia, namely traditional fermented fish, "rusip" and "bekasam" showed great ACE inhibitory activities. As reported by Subarka et al. (2019), "rusip" was fermented small fishes using salt and palm sugar showed ACE inhibitor activity up to $95 \%$. Several isolates of lactic acid bacteria were inoculated in bekasam like product showed ACE inhibitory activity ranging from 18\%-68\% (Wikandari et al., 2012).

The ACE inhibitory activity was influenced by peptide sequence derived from hydrolysis process during fermentation and ability to bind the active site of ACE (Ryan et al., 2011; Choe et al., 2019). The inhibitory activity of ACE peptide is thought to be due to the high residual hydrophobic amino acids such as proline, alanine and aliphatic amino acids such as glycine. According to Manoharan et al. (2006) peptides

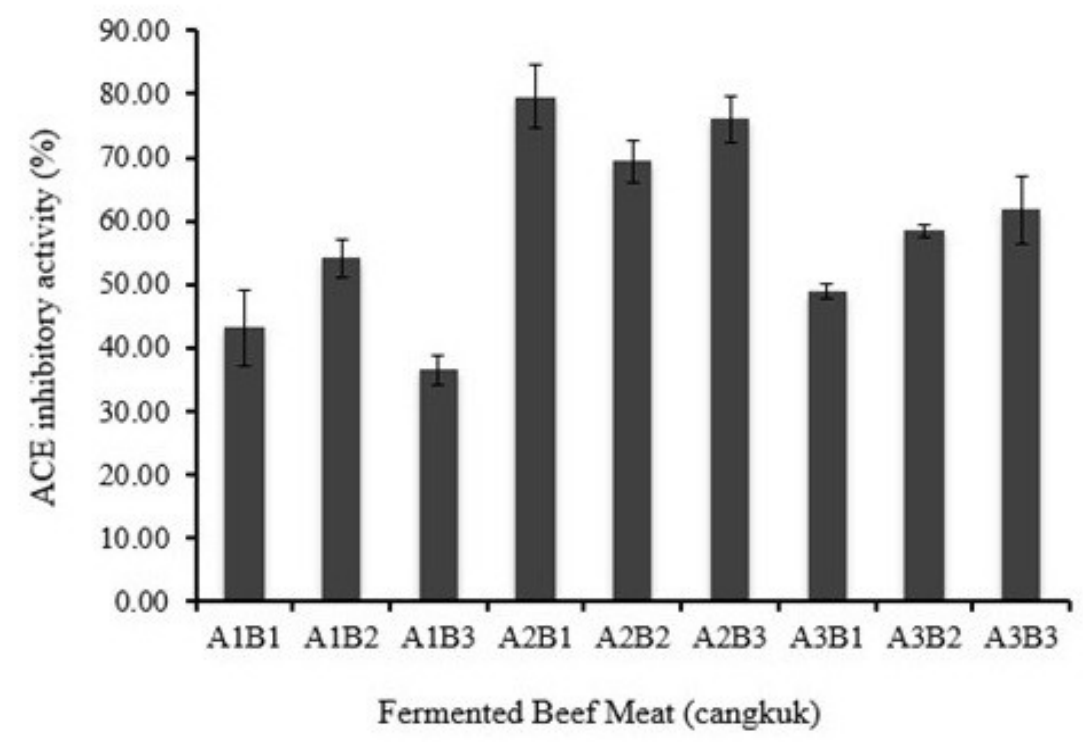

Figure 1. Angiotensin Converting Enzyme Inhibitory Activities of Fermented Beef Meat with Addition of Bamboo Shoot (cangkuk). A : preparation method of bamboo shoot (A1 : Chopped bamboo shoot, A2 : Ground bamboo shoot, A3 : Water soluble extract of bamboo shoot), B : ratio of meat and bamboo shoot (B1 : $1: 0.75, \mathrm{~B} 2: 1: 1, \mathrm{~B} 3: 1: 1.25)$ 
that have proline or aromatic residues at the Cterminal end and hydrophobic amino acid residues at the N-terminal end have potential ACE inhibitory activity. The same author stated that ACE had an important role in regulating the blood pressure. While in this research, high ACE inhibitory activity in A2B1 treatment is the basis for the second phase of this research to study the antihypertensive activity in Spontaneous Hypertensive Rats.

\section{CONCLUSION}

The results of this study show that bamboo shoot prepare through the ground process with the ratio of meat and bamboo shoot $1: 0.75$ has protruded chemical characteristics and ACE inhibitory activity. It is recommended to conduct further research using these results.

\section{ACKNOWLEDGMENTS}

The authors would like to thank the Directorate of Islamic Higher Education, Ministry of Religious Affairs, Republic of Indonesia for financial support of the research by the Programme Applied Global Research 2019 [Contract No 1967/2019].

\section{REFERENCES}

AOAC- Association Official Analytical Chemist's Technical Standard. 960-52. 2005. Official Methods of Analysis, 16th Ed. Washington.

Albenzio, M., A. Santillo, M. Caroprese, A. della Malva and R. Marino. 2017. Review. Bioactive peptides in animal food products. Food 6(35): 1-14.

Arihara, K., Y. Nakashima, T. Mukai, S. Ishikawa and M. Itoh. 2001. Peptide inhibitor for angiotensin-I converting enzyme from enzymatic hydrolisates of skeletal muscle proteins. Meat Sci. 57: 319-324.

Arihara, K. 2006. Strategies for designing novel functional meat products. Meat Sci. 74: 219-229.

Bover-Cid, S., M. Izquierdo-Pulido and M.C. Vidal-Carou. 2000. Influence of hygienic quality of raw materials on biogenic amine production during ripening and storage of dry fermented sausages. J. Food Protect. 63(11): 1544-1550.

Broncano, J.M., J. Otte, M.J. Petron, V. Parra and M.L. Timon. 2012. Isolation and identification of low molecular weight antioxidant compounds from fermented "chorizo" sausage. Meat Sci. 90(2): 494501.

Choe, J., K.H. Seol, H.J. Kim, J.T. Hwang, M. Lee and C. Jo. 2019. Isolation and identification of angiotensin I-converting enzyme inhibitory peptides derived from thermolysin-injected beef $M$. Longissimus. Asian-Australas. J. Anim. Sci. 32(3) : 1011-2367.

Choudhury, D., J.K. Sahu and G.D. Sharma. 2012. Bamboo shoot : microbiology, biochemistry and technology of fermentation-a review. Indian J. Traditional Knowledge. 11(2): 242-249.

Chusman D.W and H.S. Cheung. 1971. Spectrophotometric assay and properties of the angiotensin-converting enzyme of rabbit lung. Biochem. Pharmacol. 20: 1637-1648.

Doyle, P.M., R.L. Beuchat and J.T. Montville. 2001. Food Microbiology. Washington DC.USA.

Escudero, E., M.C. Aristoy, H. Nishimura, K. Arihara and F. Toldra. 2012. Antihypertensive effect and antioxidant activity of peptide fractions extracted from Spanish dry-cured ham. Meat Sci. 91: 306311.

Faithong, N., S. Benjakul, S. Phatcarat and W. Binsan. 2010. Chemical composition and antioxidative activity of Thai traditional fermented shrimp and krill products. Food Chem. 119: 133-140.

Fuessl, A., M. Yamamoto and A Schneller. 2012. Opportunities in Bio-Based Building Blocks for Polycondensates and vinyl Polimers. In Polymer Science: A Comprehensive Reference. 5:49-68. BASF SE, Ludwigshafen, Germany.

Hasnaliza H, M.Y. Maskat, A.W.M. Wan and S. Mamot. 2010. The effect of enzyme concentration, temperature and incubation time on nitrogen content and degree of hydrolysis of protein precipitate from cockle (Anadara granosa) meat wash water. Int. Food Research J. 17(1): 47-152.

Hui, Y. H. 2006. Handbook of Food Science, Technology, and Engineering. Volume 1. Edited by Y. H. Hui. CRC Press. Florida.

Jain, S. and A.K. Anal. 2017. Production and characterization of functional properties of protein hydrolysates from egg shell 
membranes by lactic acid bacteria fermentation. J. Food Sci. Technol. 54(5): 1062-1072.

Jamhari, J., L. M. Yusiati, E. Suryanto, M.N. Cahyanto, Y. Erwanto and M. Muguruma. 2013. Comparative study on angiotensin converting enzyme inhibitory activity of hydrolysate of meat protein of Indonesian local livestocks. J. Indonesian Trop. Anim.Agric. 38(1): 27-33.

Kameník, J., P. Steinhauserová, A. Saláková, Z. Pavlík, G. Bořilová, L. Steinhauser and J. Ruprich. 2013. Influence of various pork fat types on the ripening and characteristics of dry fermented sausage. Czech J. Food Sci. 31:419-431.

Kampen, W.H. 2014. Nutritional requirement in fermentation process. In. Fermentation and Biochemical Engineering Handbook $3^{\text {rd }}$ Edition. (H.C. Vogel and C.M. Todaro, eds). Elsevier Science. USA. p. 37-57.

Khairina, R., T. Utami and E. Harmayani. 1999. Biochemical, physical, microbiological and sensory changes of wadi walking fish. Agritech. 19(4):181-188.

Li Ping-lan, Q.W. Shen and L.V. Yan-ni. 2003. Analysis of main of microorganism in xuanwei ham. Chinese J. Microecol. 20035.

Lindayani, L. Hartajanie and M.P. Murniati. 2018. Probiotic potential of lactic acid bacteria from yellow bamboo shoot fermentation using $2.5 \%$ and $5 \%$ brine at room temperature. Microbiol. Indonesia. 12(1): 30-34.

Manoharan, S., A.S. Shuib and N. Abdullah. 2017. Structural characteristics and antihypertensive effects of angiotensin-Iconverting enzyme inhibitory peptides in the renin-angiotensin and kallikrein kinin systems. Afr J. Tradit Complement Altern Med. 14(2): 383-406.

Mora, L., M. Gallego and F. Toldra. 2018. ACEI inhibitory peptides naturally generated in meat and meat products and their health relevance. Review. Nutrient. 10(9):1259

Nielsen, P.M., D. Petersen and C. Dambmann. 2001. Improved method for determining food protein degree of hydrolysis. J. Food Sci. 66(5): 642-646.

Ockerman, H.W. and L. Basu. 2017. Current status of fermented meat production In Fermented Meat Products Health Aspects. (N Zdolec Ed). CRC Press. Boca Raton
New York. p. 572.

Owens, D.J. 2015. Indigenous Fermented Foods of Southeast Asia. CRC Press Taylor \& Francis Group. New York.

Radiati, L.E., A.K. Umam, A. Susilo and A.A. Thoifi. 2020. Effect of L. plantarum concentration level on physicochemical properties of fermented goat meat dendeng. IOP Conf. Series : Earth and environmental Science. The $4^{\text {th }}$ Animal Production International Seminar, Malang 24-27 October 2019. 478. 012038.

Rahayu, E.S. 2003. Lactic acid bacteria in fermented foods of Indonesian origin. J. Agritech. 23(2): 75-84.

Rahman, A., S. Fardiaz, W.P. Rahayu, Suliantari dan C.C. Nurwitri. 1992. Teknologi Fermentasi Susu. Penerbit Pusat Antar Universitas, Institut Pertanian Bogor. Bogor.

Ruiz, J.N., N.D.M. Villanueva, C.S. FavaroTrindade and C.J. Contreras-Castillo. 2014. Physicochemical, microbiological and sensory assesments of Italian salami sausages with probiotic potential. Scienta Agricola. 71(3): 204-211.

Rutherfurd, S.M., 2010. Methodology for determining degree of hydrolysis of protein in hydrolysates : a review. J. AOAC Int. 93(5): 1515-22.

Ryan, J.T., R.P. Ross, D. Bolton, G.F. Fitzgerald and C. Stanton. 2011. Bioactive peptides from muscle source : meat and fish. A review. Nutrient. 3: 765-791.

Salahuddin. 2004. Kajian Fermentasi Cangkuk dari Daging Sapi dan Rebung Bambu Betung (Dendrocalamus asper). Thesis. Sekolah Pascasarjana. Institut Pertanian Bogor. Bogor

Singh, V.P., V. Pathak and A.K. Verma. 2012. Fermented meat product : organoleptic qualities and biogenic amines- a review. American J. Food Tech. 7(5):278-288.

Soenarno, M.S., B.N. Polli, A. Febriantosa, dan R. Hanifah. 2013. Identifikasi peptida bioaktif dari olahan susu fermentasi tradisional Indonesia sebagai bahan pangan fungsional untuk kesehatan. J. Ilmu Produksi dan Teknologi Hasil Peternakan. 1(3): 191-195.

Steel, R.G.D. and J. H. Torrie. 1980. Principles and Procedures of Statistics, a Biometrical Approach. McGraw-Hill International Book Company. $2^{\text {nd }} E d$. 
Steinkraus, K.H. 2002. Fermentations in world food processing. Comprehensive Review in Food Science and Food Safety. 1:23-32.

Subarka, H., Rinto and A. Baehaki. 2019. Study of antioxydant activity, anticholesterol and antihypertensive activity of extract "Rusip". J. Fishtech. 8(1):18-26.

Umam, A.K., L.E. Radiati, A.Susila and R.N. Hapsari. 2019. Chemical and microbiological quality of fermented goat meat dendeng with different levels of $L$. plantarum. IOP. Conf. Series: Earth and Environmental Science 387.012012.

Waterborg, J.H. 2002. The Lowry method for protein quantitation. In The Protein Protocols Handbook (J.M. Walker Ed.): second edition. Humana Press, Inc. New Jersey. (p.7-9).

Wikandari, P.R., Suparmo, Y. Marsono and E.S. Rahayu. 2012. Potency of lactic acid bacteria isolated from Bekasam as ACE inhibitor produccing-bacteria in fermentation of Bekasam-like product. J. Agritech. 32(3): 258-264.

Winarti, A., F. Rahmawati, N.A. Fitriyanto, J. Jamhari and Y. Erwanto. 2019. Hydrolyzation of duck meat protein using Bacillus cereus TD5B protease, pepsin, trypsin and their potency as an angiotensin converting enzyme inhibitor. J. Indonesian. Trop.Anim.Agric. 44(3):266-276.

Wu, J., W. Liao, and C.C. Udenigwe. 2017. Revisiting the mechanism of ACE inhibitory peptides from food protein. Trends Food Sci. Technol. 69: 214-219.

Yana, N.Y.D., B. Dharma, and R.A. Nugroho. 2016. Karakterisasi dan identifikasi bakteri dari tamba daging babi (Sus sp) hasil fermentasi spontan. J. Bioprospek. 11(2): 53-60.

Zhou, G.H. and G.M. Zhao, GM. 2007. Biochemical changes during processing of traditional Jinhua ham. Meat Science. 77(1): 114-120.

Zhou, Y., Y. Ma, G. Yao, J. Li and S. Wang. 2017. Changes of protein composition and its relevance with textural properties during processing of fermented solid beef. J. Food Process. Preserv. https://doi.ord/10.1111/ jfpp. 13224.

Zivkovic, D., Z. Radulovic, S. Aleksic, M. Perunovic, S. Stajic, N. Stanisic and C. Radovic. 2012. Chemical, sensory and microbiological characteristics of Sremska sausage (traditional dry-fermented Serbian sausages) as affected by pig breed. African J. Biotech.11(16): 3858-3867. 